\title{
Diverse Uses of Feathers with Emphasis on Diagnosis of Avian Viral Infections and Vaccine Virus Monitoring
}

\section{author(s)}

Davidson I

Mail Address

Irit Davidson

Kimron Veterinary Institute, Bet Dagan

P.O.Box 12, Israel 50250

E-mail: davidsoni@int.gov.il

\section{Keywords}

Avian influenza virus, avian retroviruses, infectious laryngotracheitis virus, circoviruses, chicken, chicken anemia virus, diagnosis of avian viral diseases, environmental monitoring, feathers, fowlpox virus, Marek's disease virus, malformation of chick feathering, stability of DNA viruses, usage of feathers.

\section{Acknowledgement}

We are grateful for the collaboration to Dr. Shimon Pokamuski, Chief Poultry Disease Officer, Veterinary Services and Animal Health, Ministry of Agriculture, Israel, and to all field poultry veterinarians that sent us over the years the clinical samples for diagnosis.

\section{ABSTRACT}

The large amounts of feathers produced by the poultry industry, that is considered as a waste was explored for possible uses in various industries, such as meals for animals, biofuels, biodegradable plastic materials, combating water pollution and more. That review mentions these uses, but concentrate on the utilization of feathers for the diagnosis of viral infections and for monitoring vaccine viruses in chickens after vaccination. The viral diseases in which diagnosis using nucleic acids extracted from the feather shafts was described are, Marek's disease virus, circoviruses, chicken anemia virus, fowlpox virus, avian retroviruses, avian influenza virus and infectious laryngotracheitis virus. In two cases, of Marek's disease virus and of infectious laryngotracheitis virus, the differentiation of vaccine and wild-type viruses from feather shafts was made possible, thus allowing for monitoring the vaccination efficacy. The present review demonstrates also the stability of DNA viruses in feather shafts, and the possible evaluation of environmental dissemination of pathogens. When viruses are transmitted vertically, like in the cases of the retrovirus REV, a teratogenic effect on the development of feathers of the day-old newly hatched chick might occur in the case of avian influenza and the chicken anemia virus, which might indicate on a viral infection

\section{Feathers}

Feathers are one of the most prominent features of a bird's anatomy, and they are unique to birds. Feathers are made up of keratin, an insoluble protein that is also found in mammalian hair, hoofs, horns, wool and reptilian scales. Every bird has feathers and everything that has feathers is a bird. Feathers carry out several functions for a bird, (a) they provide waterproofing and insulation, that is important in the warm blooded birds, whose body temperature is maintained at around 40C; (b) protection from UV light; (c) except of domestic poultry, most notable is the critical role that feathers play in enabling birds to fly; (d) feathers are indicative of the welfare status of birds, or oppositely, of physiological stress, like molting (Leeson \& Walsh, 2004a).

The poultry industry generates large amounts of feathers as a byproduct, which is perceived as useless waste, therefore, much effort is addressed to disposal. Moreover, abundant feather debris is considered delirious to human health and imposes an unnecessary burden of poultry pathogens.

In quite the opposite, the present review displays several novel uses of poultry feathers with a particular detailed focus on poultry health concerns. Accordingly, the use of feather shafts of chickens for the diagnosis of viral infections and for the monitoring vaccine viruses in chickens after vaccination create the core of the present reviewed. 


\section{Alternative uses of chicken feathers}

Feather were used as an ingredient of food for animals and as a fertilizer because of its high protein and nitrogen content, however, these methods are costly and controversial. With increasing concerns over diseases such as spongiform encephalopathy, or mad cow disease, using animal waste in animal feed is becoming increasingly unpopular.

Feathers contain as much as 12 percent fat content, thus feather meals had potential to be used as an alternative (Moritz \& Latshow,2001; Liu et al., 1989), non-food feedstock for the production of biofuel. A new process for extracting fat from chicken feather meal was developed using boiling water and its procession to biodiesel was further explored.

Feathers were alternatively used also for the development of a biodegradable plastic, as nitrogen release from feather fibers is slow, and after use, that plastic can be added to compost piles for decomposition. Chicken feathers are made mostly from keratin, a protein which has a high cysteine concentration (Humeniuk \& Robak, 1993). The sulphur atoms in the cysteine residues tend to cross-link with one another, rendering the protein tough, strong and lightweight. Breaking of the disulfide linkages in the protein, dissolution and shape formation and reformation of the disulfide linkages are critical for the diverse uses of this protein. Several types of plastic for diverse uses, were developed, ranging from paper pulp, textiles, polymer films made as thin sheets of plastic similar to cellophane to dense and less dense plastic composites for products such as car dashboards, plant pots, boat exteriors, hurricane-resistant roofing, biodegradable plates, etc. (Schrooyen et al.,2001; Martindale, 2000).

Surprisingly, chicken feathers have been introduced into use also for combating water pollution with highly toxic heavy metals that are released to the environment through industrial effluents (De la Rosa et al., 2008). Heavy metals, and particularly $\mathrm{Pb}$ are nonbiodegradable, tend to accumulate and cause several diseases and health disorders in humans and in other living organisms. The chicken feathers were developed as an alternative and promising biosorbent for $\mathrm{Pb}$ removal from aqueous solutions. In contrast to the novel use of feather sorbents, the commonly used technologies for heavy metal removal involved chemical precipitation and filtration, chemical oxidation, electrochemical treatment, reverse osmosis, evaporation, ion-exchange and sorption, and may show economical and technical disadvantages.

\section{Uses of feathers for the assessment of virus infections in poultry}

At the base of each feather, the rachis expands to form the hollow tubular calamus, or shaft, which inserts into a follicle in the skin. As the feather section that is embedded within the skin follicle has an opening at its base enabling blood components to reach that site, the content of the feather shaft represents both the blood content and the feather follicle walls. By sampling the feather shafts we expected to detect avian viruses that replicate in epithelial cells of the feather follicle, in other cells that circulate throughout the body and reach the feather pulp, or are excreted to the blood. Flint et al. (2004) described the epidermis, the outer layer of the feather follicle, as a tissue that has poor host immune response against viral replication; therefore, viruses may be able to survive longer in differentiated epidermal tissue such as contour feathers.

The use of feather shafts to detect avian pathogens is advantageous and seems straightforward, especially after demonstrating if their usefulness in virus detection; feathers are easy for sampling, bleeding and necropsy are avoided and repeated sampling can be performed from the same birds. Feathers are living tissues that are easily collectible from live birds with minimal damage. Moreover, as feathers are disseminated in poultry houses and into the poultry house surroundings, they are readily available, and the load of environmental contamination with avian pathogens can be estimated.

In a previous review we described the available knowledge gained by studies performed until five years ago (Davidson \& Shkoda, 2005), regarding three avian DNA viruses, Marek's disease virus (MDV) (Schat \& Nair, 2008), chicken anemia virus (CAV) (Schat \& Woods, 2008), and fowlpox virus (FPV) (Tripathy \& Reed, 2008) and two avian retroviruses, reticuloendotheliosis virus (REV) (Fadly et al., 2008) and avian leukosis virus subgroup J (Fadly \& Nair, 2008; Payne, 1998). The present review will present briefly these data and will emphasize the novel knowledge that was gained recently, and will present for the first time the knowledge on two viruses, that were approached for the first time regarding their presence in feathers, avian influenza virus (Swayne \& Halvorson, 2008) and infectious laryngotracheitis virus (Guy \& Garcia, 2008). In addition, a special emphasis will be dedicated to the differentiation between wild-type and vaccine virus strains and to the detection of the two virus types in feathers, incase of MDV and ILTV and their vaccine strains in feather shafts. 
While DNA viruses possess high stability on dry shredded feathers, debris, keratinized cells and poultry house dust, retroviruses are unstable in their RNA form. However, the retroviruses replication within the cells employ a rapid transition to DNA by a reverse transcriptase step, following which the viral genome is incorporated into the cellular genome and transmitted as DNA viruses.

\section{Feathers and Marek's disease virus}

MDV is a herpesvirus that causes tumors, immunosuppression and neurological symptoms. The virus replicates in the feather follicle epithelium cells and spreads horizontally with dust and dander in the poultry houses. The virus spread out to the environment via skin stratified squamous epithelium cells, which commonly detach with molted feathers or skin renewal. Extensive studies were dedicated to the MDV replication, presence and spreading pattern of MDV in feathers (reviewed by Schat \& Nair, 2008).

The initial studies of Calnek \& Hitchner commencing in 1969 described the feather follicle epithelium (FFE) as the only anatomical site in the bird where productive replication of MDV occurs and enveloped virions were found (Calnek \& Hitchner, 1973). Conversely, Heidari et al. (2007) study introduced a shadow of doubt in the dogma that only feather follicle cells carry MDV. By using scaleless chickens whose skins contain only a few scattered feathers and no normal plumage and feather follicles, they showed that these birds can also disseminate horizontally MDV to contact cage-mates, although with a delay of about 4 days. It was not possible to define whether the feather follicle cells, containing the shafts of the few existing feathers are responsible for the replication and spread of MDV, or whether all epithelial cells carry MDV replication.

Further studies by Calnek, Nazerian, Witter and others showed that the cell free infectious virus which was contained in dander, poultry house and feather dust was responsible for the vertical spread and transmission of Marek's disease (Beasley et al., 1970; Calnek et al., 1970; Carroza et al., 1973). The early studies also showed that commercial air filters were efficient in removing MDV particles from the air (Burmester \& Witter, 1972).

The prominent trait of MDV to be produced, accumulated on the feather shafts and pulp and to remain infective on dry feathers was utilized in our studies for the last 25 years at the Kimron Veterinary Institute, Bet Dagan, Israel. We aimed to determine the presence and the kinetics of the MDV shedding by analysing the viral antigens and DNA by the ELISA and dot blot hybridization (Davidson et al., 1986; Malkinson et al., 1989) or by PCR of commercial flocks of chickens and turkeys (Davidson et al., 1995). Both MDV antigens and DNA were detected in the feather tips of injected birds commencing on day 11 post infection, and twoweeks later, the in-contact infected birds became also positive (Davidson et al., 1986; Malkinson et al., 1989).

Further, two novel uses of the feather tip extracts were developed; a) the large ( 200 kbp) MDV genome was separated directly from feather shafts of infected chickens using Pulsed Field Gel Electrophoresis (Borenshtain \& Davidson, 2002); b) experimental MDV infection was induced by dripping feather tip extracts on the mouth of one day-old Specific Pathogen Free chicks (Davidson \& Borenshtain, 2003). By that approach we could reproduce, for the first time, the disease by infecting the mucosal surface of the eyes and airways. That approach was novel, as the intraperitoneal injection was routinely used in MDVinfection trials and the natural route of MDV infection is by the airways gateway. Also, while most studies described the use of MDV in its cell-associated status, in either blood or culture cells, we originally used cellfree virus, that is uniquely present in the feather tips. By applying the feather tip extract directly on the mucous surface of the chicken both criteria were met, a synchronous infection was achieved and the technical problems associated with an alternative method of insufflating MDV-infective dust into the lower trachea (Butter et al., 2007) were avoided. Moreover, the direct application of feather tip extracts onto the mucous surfaces of the respiratory tract, was further used by us to study other viruses, like CAV, that were found in feather tip extracts (see below chapter on CAV).

The recent accessibility of the real-time PCR technology brought to the development of highly sensitive methods of MDV detection in the feather shafts and to the differentiation between wild-type and vaccine viruses and viral quantification by the real-time PCR method (Baignet et al., 2004; Abdul-Careem, 2006). However, the data obtained by the real time PCR was confirmatory to data previously obtained by the standard PCR method regarding the kinetics of appearance of MDV in feathers (Malkinson et al., 1989). Its increased sensitivity enabled the virus detection two days before the conventional PCR have indicated. However, a higher sensitivity of detection is not warranted for clinical cases, because the enhanced chances of contamination, and because the severity of disease is proportional to the amount of feather secreted MDV. 
Recently several studies attempted to identify and quantify by the real-time PCR methodology the three MDV serotypes of MDV and enable the differentiation between MDV vaccine virus strains and wild-type virulent MDV. That application might enable monitoring of MDV vaccines on the background of virulent MDV infection (Islam et al., 2006; Renz et al., 2006). Several studies were dedicated to develop prediction methods for assessing the vaccination efficacy, based on the differential quantities of the vaccine and wild-type viruses, however, these studies resulted by now in contradictory conclusions (Islam \& Walkden-Brown, 2007; Islam et al., 2008; Baignet et al., 2007).

Recently, in parallel with an increase in viral genome load and viral replication in the feather, local immune responses were first described to occur at the feather follicle epithelium. There was a gradual but progressive increase in infiltration of CD4+ and CD8+ T cells into the feather pulp of MDV-infected chickens, starting on day 4 and peaking by day 10 post-infection (AbdulCareem et al., 2008a,b).

\section{Feathers and avian influenza virus}

Since the avian influenza epidemics in 1997 in Asia, numerous studies have been dedicated to the avian influenza virus (AIV) epidemiology and characterization, however, only one study have inquired the relevance of feathers in the AIV biology. Yamamoto et al. (2007a) investigated the pathological changes in feathers of call ducks after intranasal infection with AIV strain $\mathrm{H} 5 \mathrm{~N} 1$, as waterfowl are known as the natural hosts and reservoirs of AIV. The study demonstrated that Japanese high pathogenic AIV strains can replicate in the feather epithelium cells of call ducks through the natural infection route, and these feathers can be used to create a re-infection of ducks, suggesting that feathers could be a potential source of infection for unaffected birds in nature (Yamamoto et al., 2007b). Further, replication and ultrastructural changes of two strains of H5N1 AIV were verified in domestic ducks and geese (Yamamoto et al., 2008). Although the inoculated birds did not exhibit apparent clinical signs, histologically and virologically the AIVs were demonstrated in the feather epidermal cells.

Roy et al. (1998) described an additional and advantageous use for the feather shaft content in the context of serological monitoring of antibodies in Newcastle Disease, because of the ease of the feather collection. Three weeks after booster vaccination by oculonasal route, antibody levels of serum samples were highest, followed by feather pulp and tear samples.
Although the AIV infection of poultry is acute and major routes of AIV spread are occurring through spreading of their feces and respiratory secretions, further evaluation of the dissemination potential of AIV to the environment through feathers, and their potential to infect naïve birds is needed, as feathers can drop off, blow away, or be reduced to dust. Feathers might comprise a significant route of infection in the case of AIV infection by mildly or non-virulent virus strains, in case of low virus loads, or during poultry processing to various commodities.

\section{Feathers and circoviruses}

Infections with CAV are considered economically significant because clinical disease are manifested with either visible clinical or invisible, subclinical signs. In young chicks of less than three weeks, without CAV maternal antibodies, the infection expresses by stunting, runting, increased mortality, anemia, bone marrow cell depletion, subcutaneous hemorrhage, and a decreased resistance to secondary bacterial diseases such as gangrenous dermatitis and campylobacter colonization. These effects are caused because of the multi-potent efficacy of CAV to infect and deplete stem cells of both the hematopoietic and lymphocytes cell lineages in the bone marrow. In older chickens the virus decreases several immune responses and increases morbidities caused by various pathogens (Fehler \& Winter, 2001; Markowski-Grimsrud \& Schat, 2003). The disease prevalence in commercial Israeli flocks has been lately reported (Davidson et al., 2004).

CAV spreads both vertically and horizontally among chickens. In contrast to the efficient virus practical lateral dissemination in commercial flocks, as judged by the extent of spontaneous seroconvertion, limited information is presently available on CAV. In particular, the transmission routes, their impact on the chicken health, and environmentalal contamination, are mostly unknown. Feces of infected chickens were implicated in the horizontal spread during 5-7 weeks after infection (Hoop, 1992; Yuasa et al., 1983) and the oral or respiratory routes were suggested (Rosenberger \& Cloud, 1989). No attention was given to the possibility of virus spread through feathers and dander, although CAV is not enveloped and possesses therefore a remarkable stability in extreme condition. We reported for the first time, that CAV can be detected in the feather tips and infection can be diagnosed by analyzing feather tips, resembling MDV in that respect.

We recently described the role of feathers in the horizontal spread of CAV and its demonstration in the 
feather tips of experimentally infected chickens by PCR (Davidson et al., 2008a,b). Comparing DNA from feathers and lymphoid organs indicated that DNA from feathers is an excellent source for the detection of CAV. Feather follicle tissues were examined for CAV-induced lesions by histology and immunohistochemistry. Specific histological changes were found only in chickens with CAV-PCR positive feather tips. However, viral protein levels were below detection levels by immunohistochemistry (Davidson et al., 2008a). To determine whether the PCR-detected CAV sequences represent infectious virus, feather tip homogenates were used to infect oneday old chickens via the mucosal entries, i.e., eyes, nose and oropharynx. This infection route may resemble the natural mode of horizontal infection as, was previously demonstrated for Marek's disease virus (MDV) (Davidson \& Borenshtain, 2002). MDV was included in the present study to mimic the natural inoculum in field flocks, where both viruses are ubiquitous. Two groups received MDV and CAV at different viral loads, one group received MDV, and another group received uninfected control feather extract. We demonstrated that mucosal infection using feather tip inoculum reproduced infection with CAV and MDV (Davidson et al., 2008a).

Another circovirus, psitaccine beak and feather disease virus (PBFDV) (Woods \& Latimer, 2008) is shed by feathers and transmitted horizontally by feather dander, in addition to feces and crop content. As for CAV, we detected the PBFDV by PCR in feather tip extracts of diseased birds and applied the environmental monitoring approach of the cage floor using feathers (Davidson \& Bendheim, 2004).

\section{Feathers and fowlpox virus}

Pox is a viral disease of commercial poultry (chickens and turkeys), as well as of pet and wild birds (reviewed by Tripathy \& Reed, 2008). Fowlpox caused by the pox virus (FPV) is economically a significant disease because it can causes a drop in egg production and increased mortality. However, pox has a mild clinical appearance and is spreading at a slow rate, then causing discrete nodular proliferative skin lesions on the non-feathered parts of the body (cutaneous form) or fibrino-necrotic and proliferative lesions of the mucous membrane of the upper respiratory tract, mouth and esophagus (diphtheric form). A simultaneous systemic infection might appear in some cases. The FPV spreads only horizontally through aerosol and poultry house dust generated by feathers and dried scabs, although occasionally, insects were also implicated in the environmental spread of disease. Our attempts to detect FPV by PCR in chickens that bear multiple skin pox lesions were partially successful, however, as only limited data is available, it seems that the most efficient DNA source for FPV detection is the lesion itself, and further studies are warranted.

\section{Feathers and retroviruses}

Limited studies were dedicated to the presence of retroviruses in feathers. Unlike MDV, that belongs to the herpesvirus family and is transmitted only horizontally, retroviruses are transmitted both vertically and horizontally. While MDV is relatively stable in dry feather dust, retroviruses are unstable outside the bird and require mostly a direct contact with biological material of an infected bird. For that reason the transmission of retroviruses by air is not trivial and was considered relatively unimportant, although avian leucosis virus, subgroup A (ALV-A) was detected, and even cultivated from the feather pulp and FFE (Spencer et al., 1983; 1987). The feather pulp was also suitable for the development of an ELISA test to detect the group-specific antigens (Korec et al., 1984). Recent observations of commercial flocks revealed that avian leucosis virus, subgroup J (ALV-J) spread horizontally and vertically to a greater extent than ALV-A. These epidemiological data led Koch et al. (2000) to study of the ALV-J horizontal transmission. To assess the air-borne transmission of ALV-J, wires separated the cages and a high rate of air-borne horizontal infection was evidenced by the demonstration of both virus and antibodies. A breakthrough was made in 2002, when three separate and independent studies were published, all showing that ALV-J could be detected in the feather tips of infected chickens (Davidson \& Borenshtain, 2002; Sung et al., 2002; Zavala et al., 2002).

\section{Feathers and Infectious Laryngotracheitis virus}

Infectious laryngotracheitis (ILT) is a respiratory disease of poultry caused by an alphaherpesvirus, ILTV. In our study we originally attempted to analyze directly the chicken organs, including the feather shafts, to avoid changes in the virus genome and to facilitate fast diagnosis (Davidson et al., 2009). For the first time we showed now that feather sampling is valuable in ILTV infection and vaccination diagnosis and flock monitoring. The use of feathers save the bird killing and necropsy, and enable repeated sampling.

We investigated the time interval for vaccine virus detection following commercial vaccination by the 
vent-application, which is successfully practiced in Israel. The study indicated that ILTV amplification from feather shafts was possible in clinical cases and during about a month after vaccination. Vaccine strains were identified by nested PCR for the gE ILTV gene Han \& Kim (2003), and differed of wild-type strains ILTV by two criteria: while avirulent vaccines could be detected for about a month after the vent-application, wild-type virus could be detected in conjunction to clinical signs for an unlimited time period. The vaccine ILTV was present in the bird in minute quantities compared to the wild-type virus. In support for the diminutive vaccine virus load, was the need for using the nested PCR to demonstrate the vaccine ILTV. We assessed the virus type that appeared in conjunction to the clinical signs, and showed that the clinical signs appeared in conjunction to both molecular forms of ILTV. The molecular differentiation between the wild-type and vaccine type was facilitated by digestion of the TKPD2 amplification product with the restriction enzyme Haelll, as described by Han \& Kim (2003). While the digestion of ILTV vaccine strains resulted in an uncut product, DNA purified directly from the organ of clinically affected birds resulted either in uncut or cut TKPD2 PCR product, however, both vaccine-type and wildtype ILTV viruses can cause clinical signs.

Collectively, the analysis of all flocks indicated that the vaccine virus could be detected for about one month post vaccination in about $20-40 \%$ of the chickens that were vaccinated, and the vaccination status of the flock could be determined on flock basis. For that determination, we used feather shafts from the vaccinated chickens.

\section{The stability of DNA viruses on feathers}

Calnek \& Hitchner (1973) defined the period of time in respect to the MDV viability and ability to infect experimentally tissue cultures and young chicks, as being dependent on the temperature and humidity. Their experimental trials demonstrated that increasing the temperature and humidity lead to a decrease in the virus stability. Feathers plucked from infected chickens contained MDV after storage of 3 weeks at $37.5^{\circ} \mathrm{C}$, for 8 months at room temperature, but the virus was not stable after 13 weeks under these conditions. However, when kept at $4^{\circ} \mathrm{C}$, the virus was maintained even after 3 years; elevating the humidity to $80 \%$ decreased the virus stability to more than $50 \%$ of the time. Other studies described the efficiency of air filtration to avoid environmental contamination with MDV found in dander, poultry house dust and feather particles (Burmester \& Witter, 1972). Other studies described poultry houses dust to infect chick with MDV after 4 , but not for 6 , weeks at room temperature (Beasly et al., 1970), up to 44 days after collection (Jurajda \& Klimes, 1970), or for at least 200 days at room temperature, where freezing even extended the infectivity period (Carozza et al., 1973).

As previous studies determined the prolonged stability of MDV in poultry house dust, we questioned the possibility to detect these viruses on the feather tips of feathers that were shed and spread on the poultry house floor or in the nearby (Davidson et al., 2003). To apply that approach we first analysed the ability to detect molecularly two DNA very stable viruses in dry conditions, the MDV and CAV. Feather tips of feathers from MDV of CAV-infected chickens were cut and pooled to homogenize the sampling. The tips were then distributed in groups of ten tips and kept in open microcentrifuge tubes for various periods of times. Three series of tubes were prepared and each group was incubated, as opened, at different temperature and humidity conditions. The conditions included room temperature $\left(22-25^{\circ} \mathrm{C}\right.$ at medium humidity), cold room $\left(4^{\circ} \mathrm{C}\right.$ with high humidity) and warm room $\left(37^{\circ} \mathrm{C}\right.$ with low humidity) all resembling relevant climatic situation. At each time point $(0,1,4,7,13,25$ and 32 days) DNA was purified from each tube and PCR amplified. Same procedure was applied for both series, for MDV and for CAV, where feather tips were taken from either MDV- or CAV-infected chickens, respectively. The MDV sequences were retained intact in feather tips over at least 32 days at the three conditions, where the CAV sequences were also detectable for at least 32 days at $4^{\circ} \mathrm{C}$ and $\mathrm{RT}$, but not at $37^{\circ} \mathrm{C}$. Further investigation might be needed to clarify the inability to amplify CAV sequences from feathers incubated at warm and dry conditions.

\section{Environmental monitoring of DNA viruses in commercial flocks using feathers}

The association of viruses with feathers of infected chickens and the relative high stability of DNA viruses in feather dust and dander, as well as our last finding on the prolonged period of time that the MDV and CAV could be amplified from the feather tips, droved us to extend the use of feathers for monitoring the viral contamination of the poultry house environment (Davidson et al., 2003). We focused on the feathers of commercial chickens and analyzed their value as a source of DNA for amplification. Broiler flocks with uneven and retarded growth, internal and external 
hemorrhages, necrotic dermatitis and apparent immunosupression were assayed for MDV and CAV sequences. Visceral organs, brains and feathers of sick birds, as well as feathers from the poultry house floor or nearby surrounding were analyzed. Unlike MDV, whose presence in feather tips was previously recognized, CAV and FPV detection in feathers is novel. By that application we showed the first time that the PCR can be used as a monitoring tool for the evaluation of environmental contamination in poultry houses that can be used as a potential signal for insufficient biosecurity. Followed our study, a recent report was published, describing the poultry house dust as an efficient source of DNA for MDV amplification, used for monitoring of the MD status in commercial chicken flocks (Walden-Brown et al., 2004). Further studies might shed light to the possibility to survey and control the avian infectious diseases that are caused by relatively stable horizontally transmitted viruses.

We utilized that approach to evaluate the presence of the PBFDV in the feathers that were shed by affected pssitacines, thus exemplifying a possible way to control the biosecurity in the surroundings of breeder birds (Davidson \& Bendheim, 2004).

\section{Detection and diagnosis of viral infections in commercial flocks}

In spite of the great importance of the feathers as a source of horizontally disseminated DNA viruses, and their relatively high stability, no much attention has been dedicated to the study of their presence and use of the feather tips for diagnosis. Exceptionally, in the MDV research the feathers were emphasized, since these are the only sites where fully infectious viruses are produced in the chicken. Zanella pioneered the possibility to use feather tips for diagnosis and the evaluation of MD prognosis and summarized lately his twenty-year experience with the agar gel precipitation test (Zanella et al., 2004). We extended the virus diversity for which we explored the feathers for being used as the diagnostic sample, to MDV, REV, ALV-J, CAV and FPV. The differential diagnosis results performed by us on more than 1000 commercial flocks were reviewed lately (Davidson et al., 2007).

\section{Malformation of the chicken embryo fathering as an indication of virus infection}

Viral and bacterial pathogens might also influence the feather development, by either a pre-hatch or a post-hatch replication in the various feather follicles or embryonic tissues (Leeson \& Walsh, 2004b). The best known pathogen regarding its influence on the chick feathering is REV, however, other viruses were described as teratogenic for the chick feathering.

When transmitted vertically, REV causes degeneration and necrosis of the embryonic feather-forming cells, which lead to a typical abnormal feathering, called "Nakanuke". The syndrome is characterized by thinness and increased transparency of the calamus and rachis and by a characteristic loss of barbs (Tajima et al., 1977). Feather abnormalities were observed to be associated also with a paramyxovirus-1 pigeon variant in pigeons and chickens (Lemahieu et al., 1985).

The effect of influenza C virus, strain 33/50 on the development of chicken embryos, that were infected at 10-12 embryonic day was documented by gross observation and microscopically at hatch (Spence \& O'Callaghan, 1985). The infected newly hatched chicks displayed marked abnormalities in their feathering. The lesions appeared due to hypertrophy and/or hyperplasia of the developing barb and barbule cells. When the infection day was delayed by 2 days, no feathering lesions were formed, indicating a time-specific teratogenic effect of the AIV on the embryonic tissue. It seems also that the AIV has a specific teratogenic effect on sites of virus replication in rapidly differentiating tissues. A teratogenic effect was also observed by us upon embryonic replication of CAV, although the specific effect on the chick feathering has not been focused (Davidson et al., 2008b).

In conclusion, as several viruses show teratogenic effects on the development of feathers of the day-old newly hatched chick, that feature might be explored further during the visual examination on the feathering appearance on the day-old chicks at the hatchery. Feathering damages might provide a gross indication on whether the chicks carry a vertical viral infection. Further in deep studies might be dedicated to establish such fast indicators for assessment of the health of the newborn chicks in the hatchery.

\section{REFERENCES}

Abdul-Careem MF, Hunter BD, Nagy E, Read LR, Sanei B, Spencer JL, Sharif $S$. Development of a real-time PCR assay using SYBR Green chemistry for monitoring Marek's disease virus genome load in feather tips. Journal of Virological Methods 2006; 133:34-40.

Abdul-Careem MF, Hunter BD, Sarson AJ, Parvizi P, Haghighi HR, Read L, Heidari M, Sharif S. Host responses are induced in feathers of chickens infected with Marek's disease virus. Virology 2008a; 370: 323-332. 
Abdul-Careem MF, Hunter BD, Shanmuganathan S, Haghighi HR, Read L, Heidari M, Sharif S. Cellular and cytokine responses in feathers of chickens vaccinated against Marek's diseases. Veterinary Immunology and Immunopathology 2008b; 126:362-366.

Baigent SJ, Currie RJ, Nair VK. Quantification of Marek's disease virus load in feather tips and lymphocytes using real-time PCR. Proceedings of the 7th Internacional Marek's Disease Symposium; 2004 14-15 jul; Oxford, UK.

Baigent SJ, Smith LP, Currie RJ, Nair VK. Correlation of Marek's disease herpesvirus vaccine virus genome load in feather tips with protection, using an experimental challenge system. Avian Pathology 2007; 36:467-474.

Beasley JN, Patterson LT, McWade DH. Transmission of Marek's disease by poultry house dust and chicken dander. American Journal of Veterinary Research 1970; 31:339-344.

Borenshtain R, Davidson I. Marek's disease virus genome separation from feather tip extracts by Pulsed Field Gel Electrophoresis. Journal of Virology Methods 2002; 101:169-174.

Burmester BR, Witter RL. Efficacy of commercial air filters against Marek's disease virus. Applied Microbiology 1972; 23:505-508.

Butter C, Staines K, Baaten B, Smith L, Davison TF. Route of challenge is critical in determining the clinical outcome of infection with a very virulent oncogenic herpesvirus, Marek's disease virus. Avian Pathology 2007; 36:93-99.

Calnek BW, Adldinger HK, Kahn DE. Feather follicle epithelium: a source of enveloped and infectious cell-free herpesvirus from Marek's disease. Avian Diseases 1970; 14:219-233.

Calnek BW, Hitchner SB. Survival and disinfection of Marek's disease virus and effectiveness of filters in preventing airborne dissemination. Poultry Science 1973; 52:35-43.

Carrozza JH, Fredrickson TN, Prince RP, Luginbuhl RE. Role of desquamated epithelial cells in transmission of Marek's disease. Avian Diseases 1973; 17:767-781.

Davidson I, Artzi N, Shkoda I, Lublin A, Loeb E, Schat KA. The contribution of feathers in the spread of chicken anemia virus. Virus Research 2008a; 132:152-159.

Davidson I, Bendheim U. Molecular identification and prevalence od psittacine circovirus in Israel [ECAMS 26]. Proceedings of the 8th European Association of Avian Veterinarians Conference; 2004.

Davidson I, Borenshtain R. Novel applications of feather tip extracts from MDV-infected chickens; diagnosis of commercial broilers, whole genome separation by PFGE and synchronic mucosal infection. FEMS Immunology and Medical Microbiology 2003; 38: 199-203.

Davidson I, Borenshtain R. The feather tips of commercial chickens are a favorable source of DNA for the amplification of Marek's disease virus and avian leukosis virus, subgroup Journal Avian Pathology 2002; 31:237-240.
Davidson I, Borowski A, Perl S, Malkinson M. Use of the polymerase chain reaction for the diagnosis of natural infection of chickens and turkeys with Marek's disease virus and reticuloendotheliosis virus. Avian Pathology 1995; 24:69-94.

Davidson I, Kedem M, Borochovitz H, Borenshtain R, Hamzani E, Smith $B$. Detection and environmental monitoring of DNA viruses using the feathers of commercial chickens. Denver: Annual Meeting WPSA/AAAP; 2003.

Davidson I, Kedem M, Borochovitz H, Kass N, Ayali G, Hamzani E, Perelman B, Smith B, Perk S. Chicken Infectious Anemia virus infection in Israeli commercial flocks; Virus amplification, clinical signs, performance and antibody status. Avian Diseases 2004; 48: 113-123.

Davidson I, Loeb E, Lublin A, Perk S, Shkoda I, Schat KA. Assessment of various criteria to determine to determine the chicken anemia virus pathogenicity in embryonated eggs and in day-old chicks. Current Topics in Virology 2008b; 6:95-111.

Davidson I, Malkinson M, Strenger C, Becker Y. An improved ELISA method using a streptavidin-biotin complex for detecting Marek's Disease virus antigens in feathers of infected chickens. Journal of Virological Methods 1986; 14:237-241.

Davidson I, Nagar S, Ribshtein I, Shkoda I, Perk S, Garcia M-C. Detection of wild- and vaccine-type avian infectious laryngotracheitis virus in clinical samples and feather shafts of commercial chickens. Avian Diseases 2009; In Press.

Davidson I, Shkoda I. The impact of feathers on the detection and study of DNA viral pathogens in commercial poultry. World's Poultry Science Association Journal 2005; 61:407-417

Davidson I. Avian oncogenic viruses: The correlation between clinical signs and molecular virus identification, knowledge acquired from the examination of over 1000 flocks. Israel Veterinary Medical Journal 2007; 62:42-47.

De la Rosa G, Reynel-Avila HE, Bonilla-Petriciolet A, Cano-Rodriguez I, Velasco-Santos C, Martinez-Hernandez AL. Recycling poultry feathers for $\mathrm{Pb}$ removal from wastewater: kinetic and equilibrium studies. World Academy of Science, Engineering and Technology 2008; 47: 394-400.

Fadly AM, Nair V. Leukosis/Sarcoma Group In: Saif YM, Fadly AM, Glisson JR, McDougald LR, Nolan LK, Swayne DE, editors. Diseases of poultry. 12th ed. Ames: lowa State Press; 2008. p. 514-568.

Fadly AM, Zavala G, Witter RL. Reticuloendotheliosis. In: Saif YM, Fadly AM, Glisson JR, McDougald LR, Nolan LK, Swayne DE, editors. Diseases of poultry, 12th ed. Ames: lowa State Press; 2008. p.568588.

Fehler F, Winter C. CAV infection in older chickens: An apathogenic infection? The International Symposium on Infectious Bursal Disease and Chicken Infectious Anaemia; 2001; Rauischholzhausen, Germany. p. 391-394.

Flint SJ, Enquist LW, Racaniello VR, Skalka AM. Principles of virology: molecular biology, pathogenesis, and control of animal viruses: 
patterns of infection. 2nd ed. Washington: American Society for Microbiology; 2004. p. 596-621.

Guy JS, Garcia M. Laryngotracheitis In: Saif YM, Fadly AM, Glisson JR, McDougald LR, Nolan LK, Swayne DE, editors. Diseases of poultry, 12th ed. Ames: lowa State Press; 2008. p. 137-153.

Halford B,Washington C\&EN. Going beyond feather dusters. Science and Technology 2004; 82:36-39. Available from: http:// pubs.acs.org/email/cen/html/112704004910.html, http:// www.americanfarm.com/Poultry6.13.2006a.html.

Han MG, Kim SJ. Efficacy of live virus vaccines against Infectious laryngotracheitis assessed by polymerase chain reaction-restriction fragment length polymorphism. Avian Diseases 2003; 47:261-271.

Heidari M, Fitzgerald SD, Zhang HM, Silva RF, Lee LF, Dunn JR. Marek's disease virus-induced skin leukosis in scaleless chickens: Tumor development in the absence of feather follicles. Avian Diseases 2007; 51:713-718.

Hoop RK. Persistance and vertical transmission of chicken anemia agent in experimentally infected laying hens. Avian Pathology 1992; 21:493-501.

Humeniuk VV, Robak VI. High sulphur protein subunits in keratins. Ukrainian Biokhim Zb 1993; 65:3-10.

Islam A, Cheetham BF, Mahony TJ, Young PL, Walkden-Brown SW. Absolute quantitation of Marek's disease virus and herpesvirus of turkeys in chicken lymphocytes, feather tip and dust samples using real-time PCR. Journal of Virological Methods 2006; 132:127-143.

Islam A, Walkden-Brown SW. Quantitative profiling of the shedding rate of three Marek's disease Virus (MDV) serotypes reveals that challenge with virulent MDV markedly increases shedding of vaccinal viruses. Journal of General Virology 2007; 88:2121-2128.

Islam AF, Walkden-Brown SW, Groves PJ, Underwood GJ. Kinetics of Marek's disease virus (MDV) infection in broiler chickens: 1. Effect of varying vaccination to challenge virus on vaccinal protection and load of MDV and herpesvirus of turkey in the spleen and feather dander over time. Avian Pathology 2008; 37:225-235.

Jurajda V, Klimes B. Presence and survival of Marek's disease agent in dust. Avian Diseases 1970; 17:188-190.

Koch G, Van der Velde J, HartogL, Gielkens ALJ, Landman WJM. Horizontal and vertical transmission of ALV-J and ALV-A virus in broiler breeders chickens. Proceedings of the International Symposium on ALV-J and other avian retroviruses; 2000; Rauischholzhausen, Germany. p. 141-151.

Korec E, Hlozanek I, Benda $\mathrm{V}$. A rapid detection of avian oncovirus group-specific antigens in feather pulp by enzyme-linked immunosorbent assay. Folia Biology 1984; 30:15-23.

Leeson S, Walsh T. Feathering in commercial poultry I. Feather growth and composition. Poultry Science 2004a; 60:42-51.

Leeson S, Walsh T. Feathering in commercial poultry II. Factors influencing feather growth and feather loss. Poultry Science 2004b; 60:52-63.
Lemahieu P, Devriese I, Bijnens B. Feather abnormalities associated with paramyxovirus-1 pigeon variant in pigeons and chickens. Veterinary Record 1985; 116:591.

Liu JK, Waibel PE, Noll SL. Nutritional evaluation of blood meal and feather meal for turkeys. Poultry Science 1988; 68:1513-1518.

Malkinson M, Davidson I, Strenger C, Weisman Y, Maray T, Levy H, Becker Y. Kinetics of the appearance of Marek's disease virus (MDV) DNA and antigens in the feathers of chickens infected with virulent MDV field isolates as measured by AGP, ELISA and dot-blot hybridization. Avian Pathology 1989; 18:735-744.

Markowski-Grimsrud CJ, Schat KA. Infection with chicken anemia virus impairs the generation of pathogen-specific cytotoxic T lymphocytes. Immunology 2003; 109:283-294.

Martindale D. Car parts from chickens. Researchers hatch a plan to make plastic from feathers. Scientific American 2000; 282:26.

Moritz JS, Latshow JD. Indicators of nutritional value of hydrolyzed feather meal. Poultry Science 2001; 80:79-86.

Payne L N HPRS-103: a retrovirus strikes back. The emergence of subgroup J avian leucosis virus. Avian Pathology 1998; 27:S36S45

Renz KG, Islam A, Cheetham BF, Walkden-Brown SW. Absolute quantification using real-time polymerase chain reaction of Marek's disease virus serotype 2 in field dust samples, feather tips and spleens. Journal of Virological Methods 2006; 135:186-191.

Rosenberger JK, Cloud SS. The effects of age, route of exposure and coinfection with infectious bursal disease virus on the pathogenicity and transmissibility of chicken anemia agent (CAA). Avian Diseases 1989; 33:753-759.

Roy P, Koteeswaran A, Sridevi P, Venugopalan AT. Comparison of Newcastle disease vaccines by serology using serum, tears and feather pulp samples. Tropical Animal Health Production 1998; 30:31-35.

Sawyne DE, Halvorson DA. Influenza. In: Saif YM, Fadly AM, Glisson $J R$, McDougald LR, Nolan LK, Swayne DE, editors. Diseases of poultry. 12th ed. Ames: lowa State Press; 2008. p. 153-185.

Schat KA, Nair V. Marek's disease virus. In: Saif YM, Fadly AM, Glisson JR, McDougald LR, Nolan LK, Swayne DE, editors. Diseases of poultry. 12th ed. Ames: lowa State Press; 2008. p. 449-514.

Schat KA, Woods LW. Circovirus infections, Chicken infectious anemia. In: Saif YM, Fadly AM, Glisson JR, McDougald LR, Nolan LK, Swayne DE, editors. Diseases of poultry, 12th ed. Ames: lowa State Press; 2008. p 209-235.

Schrooyen PM, Dijkstra PJ, Oberthur RC, Banties A, Feijen J. Partially carboxymethylated feather keratins. 2. Thermal and mechanical properties of films. Journal of Agricultural Food Chemistry 2001; 49: 221-230. Available from: http://www.foodreference.com/html/ f-chicken-feathers.html

Spence HA, O'Callaghan RJ. Induction of chick embryo feather 


\section{Davidson I}

malformations by an influenza C virus. Teratology 1985; 32:57-64.

Spencer J L, Gavora JS, Gilka F. Detection of lymphoid leukosis virus infected chickens by testing for group-specific antigen or virus in feather pulp. Avian Pathology 1983; 12:85-99.

Spencer, J L, Gilka F, Gavora JS. Feather pulp organ cultures for assessing host resistance to infection with avian leukosis-arcoma viruses. Avian Pathology 1987; 16:425-438.

Sung, HW, Reddy SM, Fadly AM. High virus titer in feather pulp of chickens infected with subgroup J avian leucosis virus. Avian Diseases 2002; 46:281-286.

Tajima M, Nunoya T, Otaki Y. Pathogenesis of abnormal feathers in chickens inoculated with reticuloendotheliosis virus. Avian Diseases 1977; 21:77-89.

Tripathy DN, Reed WM. Pox. In: Saif YM, Fadly AM, Glisson JR, McDougald LR, Nolan LK, Swayne DE, editors. Diseases of poultry. 12th ed. Ames: lowa State Press; 2008. p. 291-309.

Walkden-Brown S, Groves P, Islam A, Burgess S, Rubite A, Islam F. Use of quantitative real-time PCR to monitor Marek's disease virus in broiler shed dust and spleen samples. Proceedings of the 7th Internacional.Marek's Disease Symposium; 2004 jul 10-14; Oxford, UK.

Woods LW, Latimer KS. Circovirus infections of pigeons and other avian species. In: Saif YM, Fadly AM, Glisson JR, McDougald LR, Nolan LK, Swayne DE, editors. Diseases of poultry. 12th ed. Ames: lowa State Press; 2008. p. 202-212.

Yamamoto Y, Nakamura K, Kitagawa K, Ikenaga N, Yamada M, Mase M, Narita M. Severe nonpurulent encephalitis with mortality and feather lesions in call ducks (Anas platyrhyncha) inoculated intravenously with $\mathrm{H} 5 \mathrm{~N} 1$ highly pathogenic avian influenza virus. Avian Diseases 2007a; 51:52-57.

Yamamoto Y, Nakamura K, Kitagawa K, Ikenaga N, Yamada M, Mase M, Narita M. Pathogenesis in call ducks inoculated intranasally with $\mathrm{H} 5 \mathrm{~N} 1$ highly pathogenic avian influenza virus and transmission by oral inoculation of infective feathers from an infected call duck. Avian Diseases 2007b; 51:744-749.

Yamamoto Y, Nakamura K, Okamatsu M, Yamada M, Mase M. Avian influenza virus (H5N1) replication in feathers of domestic waterfowl. Emerging Infectious Diseases 2008; 14:149-151.

Yuasa NT, Taniguchi T, Imada T, Hihara H. Distribution of chicken anemia agent (CAA) and detection of neutralizing antibody in chicks experimentally inoculated with CAA. National Institute of Animal Health $1983 ; 23: 78-81$

Zanella A, Ceruti R, Volorio A. Marek's disease: diagnosis and prognostic value of agar-gel diffusion test with feather tips. Proceedings of the 7th Internacional Marek's Disease Symposium; 2004 10-14 jul; Oxford, UK.

Zavala G, Jackwood MW, Hilt DAILT. Polymerase chain reaction for detection of avian leucosis virus subgroup $J$ in feather pulp. Avian Diseases 2002; 46:971-978. 